\title{
RESPONSE OF SUNFLOWER TO DIFFERENT CROPPING PATTERNS AND N FERTILIZER RATES
}

\author{
A.I. Nawar ${ }^{(1)}$, H.M. Ibrahim(1) and H.E. Khalil ${ }^{(2)}$ \\ (1) Crop Science Department, Faculty of Agriculture, Alexandria University, Egypt \\ ${ }^{(2)}$ Agriculture Research Center, Crop Intensification Dept. Egypt
}

Received: Jun. 19, 2016

Accepted : Jun. 26,2016

\begin{abstract}
Sunflower response to four cropping systems and $30\left(N_{1}\right), 45\left(N_{2}\right)$ and $60\left(N_{3}\right)$ $\mathrm{kg} \mathrm{N} / \mathrm{fed}$. were studied at Agriculture Research Station, Alexandria University, Egypt, during 2013 and 2014 summer seasons. Cropping systems were sunflower relay-cropping into (Sun $\left.{ }_{1}\right)$ or double cropping with faba bean $\left(S_{2} n_{2}\right)$, in addition to sunflower double cropping following fodder ( $\mathrm{Sun}_{3}$ ) and silage ( $\mathrm{Sun}_{4}$ ) maize crops. Responses of head and 100-seed weights, as well as seed yield/ fed and harvest index (HI) to cropping systems, were significant over the two seasons. The highest values of those traits were obtained from relay-cropped sunflower to faba bean (Sun 1 ), however, the lowest values resulted from sunflower sowing after silage maize $\left(S_{4}\right)$, that was previously relay-cropped into faba bean. Differences in seed yield and HI, for the combined treatments, were significant, as indicated by crop systems ${ }^{*} \mathrm{~N}$ levels interaction in both seasons. The highest values of the two traits were obtained from (Sun ${ }_{1}$ ) at $45 \mathrm{~kg} \mathrm{~N} / \mathrm{fed}$, whereas, the least values resulted from $\left(\mathrm{Sun}_{4}\right)$ at $15 \mathrm{~kg} \mathrm{~N} / \mathrm{fed}$. increasing the nitrogen level from 30 to $60 \mathrm{~kg} /$ fed led to significant increases in plant height, head seed weight, seed yield/fed and harvest index in both seasons. Response of head-seed and 100-seed weight, in addition to seed yield /fed. of sunflower, as $N$ level was applied up to $45 \mathrm{~kg} \mathrm{~N} / \mathrm{fed}$. to nitrogen fertilization, was linear. Sunflower relay-cropping and growing of short season crops should be applied to enable farmers to plant more than two crops per year.
\end{abstract}

Key words: Sunflower, Cropping systems, Nitrogen fertilizer, Seed yield.

\section{INTRODUCTION}

Sunflower, that ranks second to soybean among the world's oil crops, is receiving increasing attention in Egypt as a source of vegetable oil and a way to reduce oil imports.

To reach land potential yield, multiple cropping through land, time and space dimensions represents a major procedure for increasing land use, provided, there should be an appropriate crop sequence combinations coupled with a suitable crop allocation within each sequence (Nawar et al., 2009). Intensive crop sequence means saving time enough for growing more than two crops per year (Khalil et al., 2011). Relay-cropping of sunflower into faba bean or into early maturing fodder maize will save time through elimination of turn over period between two successive crops and associate with triple, or more, sequential cropping.

The inclusion of faba bean, as a leguminous crop, with other non-legumes increases soil fertility due to $\mathrm{N}_{2}$-fixation and producing roots, able to add organic matter and scavenge nutrients from lower soil depths (Nawar, 2004 and Khalil et al., 2011). Responses of a crop to its allocation in crop sequence were reported in different studies. EL-Sodany and Abou-Elela (2012), Shaalan et al. (2014) and Ibrahim et al. (2015) found in divergent studies, that legumes improved soil quality, by increasing soil content from organic matter and added that crop sequences different in root depths were able to restore water and nutrients not accessed by their preceding crops. Khalil et al. (2004) 
Nawar, et al.,

indicated that sunflower yield and its attributes (head and 100-seed weights) tended to be higher, following legumes than non-legumes.

Nitrogen is one of the most yield-limiting nutrients for crop production and must be applied to plants for growth (Fageria, 2009). In intensive cropping systems, agricultural production has increased the use of $\mathrm{N}$ fertilizer to produce and sustain high crop yields (Nawar, 2004, Khalil et al., 2011 and Ibrahim et al., 2015). In addition to the effect of nitrogen on the number of leaves/ plant, nitrogen, also, influences leaf area generation and photosynthesis capacity as well (Khalil, 2003). The increase in $\mathrm{N}$ uptake, as $\mathrm{N}$ level increased, led to greater size of vegetative shoot system, hence, larger photoassimilates production and translocation into seeds and individual seed weight (Nawar, 2004). Different studies showed that sunflower plant height (Khalil, 2003), seed weight/ head and seed index (Gewefiel, 1997) as well as seed and straw yields (Khalil, 2003).increased with increase $\mathrm{N}$ level.

Divergent two field studies of ELNakhlawy (1993) and Khalil (2003) revealed significant linear increases in sunflower seed yield as $\mathrm{N}$ level increased.

This investigation was carried out to study the beneficial effect of relay and sequential cropping of short duration crops, as a time saving factor for multiple cropping, under different $\mathrm{N}$ levels, on sunflower, growth and productivity.

\section{MATERIALS AND METHHODS}

A two year filed study was carried out during 2013 and 2014 summer seasons at Alexandria Agricultural Research Station, Alexandria University, Egypt. This investigation was laid out to study the effect of four cropping systems on sunflower (Sakha, $53 \mathrm{cv}$ ) supplied with $3 \mathrm{~N}$ levels. The cropping systems are presented in Table (1) as a four sunflower different sequences.

In Sun 1 and Sun $_{2}$, sunflower was sown as a relay-crop into or as a sequential crop, following faba bean, respectively, however, in $\mathrm{Sun}_{3}$ and $\mathrm{Sun}_{4}$, sunflower was relaycropped, respectively, into fodder (55 days) and silage maize crop (75 days) which were grown sequentially after faba bean.

Nitrogen levels (i.e. $\mathrm{N}_{1}(=30), \mathrm{N}_{2}(=45)$ and $\mathrm{N}_{3}(=60 \mathrm{KgN})$ were supplied to sunflower, as ammonium nitrogen (33.5\%), in two equal doses, at the first and second irrigations.

A split plot design with three replicates was used where the main and sub-plots were, respectively, assigned to cropping systems and $\mathrm{N}$ levels in both seasons. Each sub-plot comprised seven ridges (each 12.6 $\mathrm{m}^{2}$ in area $=3.0 \mathrm{~m}$ long $\times 0.6 \mathrm{~m}$ wide $)$.

Table (1): Sunflower crop sequences in both experiments.

\begin{tabular}{|l|l|}
\hline Cropping system & Successive crops \\
\hline Sun $_{1}$ & fa-sunflower (relay crop). \\
\hline Sun $_{2}$ & fa-sunflower (sequential crop). \\
\hline Sun $_{3}$ & fa-fodm-sunflower (relay crop). \\
\hline Sun $_{4}$ & fa-Sim-sunflower (relay crop). \\
\hline
\end{tabular}

Where, Sun $=$ Sunflower $\quad$, Sim $=$ silage maize, fodm $=$ fodder maize and $\mathrm{Fa}=\mathrm{Faba}$ bean 
Faba bean (Giza $843 \mathrm{cv}$.) was sown on the upper and one side of ridges in hills (2 plants/ hill), spaced at $20 \mathrm{~cm}$ apart on November $15^{\text {th }}$ and $20^{\text {th }}$ during the two successive seasons. Relay-cropping of sunflower, fodder and silage maize crops (each house- hold maize seeds) was applied on March $15^{\text {th }}$ and $20^{\text {th }}$ in the first and second seasons, respectively. Meanwhile, sunflower followed fodder and silage crops, respectively, on May $15^{\text {th }}$ and June $15^{\text {th }}$, in the first season with a delay in sowing of five days for these double crops in the second season. Sunflower, as well as maize fodder crops, were relay-cropped at the last irrigation of faba bean on the second side of faba bean ridge. Other cultural practices were applied, according to recommendations.

At sunflower harvesting, the plants of inner five ridges were random taken from each experimental unit. Characters recorded for sunflower were plant height $(\mathrm{cm})$, number of leaves/ plant, head diameter $(\mathrm{cm})$, head seed weight (g), 100-seed weight $(\mathrm{g})$, seed yield $(\mathrm{kg} / \mathrm{fed})$ and harvest index $(\mathrm{HI})$. Economic evaluation, in terms of cereal units (CUs), was proposed by Brockhaus (1962) to express the agronomic gain from sunflower, based on its seed yield (the maize product), considering that each 100 $\mathrm{kg}$ seeds of sunflower seeds equals 1.5 cereal units. In addition, monetary net return/ $\mathrm{kg} \mathrm{N}$ (pound) was estimated, as an economical parameter for sunflower seed yield $($ Net return $)=$ Prices of sun flower yield - costs of agricultural practices. / $\mathrm{N}$ rate $(\mathrm{kg})$. Analysis of data was conducted, according to Gomez and Gomez (1984), using SAS ver. 9.1.3 (2007). Means were compared, using the least significant difference (LSD) value at $p \leq 0.05$.

\section{RESULTS AND DISCUSSION 1- Effect of preceding crops on growth traits of sunflower:}

The effects of preceding crops on head diameter and 100-seed weight were significant and insignificant in both seasons (Tables 2, 3 and 4). The two traits were influenced by the time proximity of faba bean to sunflower, where the more it was, the greater estimates were obtained. Sunflower relay-cropping into faba bean $\left(\mathrm{Sun}_{1}\right)$ was statistically equal to its double cropping after faba bean, compared to the other preceding crops $\left(\mathrm{Sun}_{3}\right.$ and $\left.\mathrm{Sun}_{4}\right)$. The data revealed insignificant differences among $\operatorname{Sun}_{1}, \operatorname{Sun}_{2}$ and $\operatorname{Sun}_{3}$, which were significantly greater than $\mathrm{Sun}_{4}$ in head diameter. Those observations hold fairly true during the two seasons. Faba bean, as a legume, is known to increase soil fertility, i.e. soil $\mathrm{N}$ and organic matter (Ghosh et al., 2007 and Rajaii and Dah-Mardeh, 2015) to improve soil physical properties (EL-Sodany and Abou-Elela, 2010 and Jannoura et al., 2014) and, consequently, to enhance the growth of succeeding crops.

Data, also, declared the significant response of head seed weight to the preceding crops. The greatest mean value of this trait was obtained from Sun ${ }_{1}$ (in which sunflower was relay-cropped into faba bean), however, the lowest one was associated with sunflower sequential cropping after silage maize $\left(\operatorname{Sun}_{4}\right)$. On the other hand, there were insignificant differences between $\left(\mathrm{Sun}_{3}\right)$ and $\left(\mathrm{Sun}_{4}\right)$ but significantly lower and greater than $\mathrm{Sun}_{1}$ and $\mathrm{Sun}_{4}$, respectively, regarding values of head-seed yield. These results might be attributed to the more availability of soil $\mathrm{N}$, with respect to $\left(\operatorname{Sun}_{1}\right)$ and $\left(\operatorname{Sun}_{2}\right)$, leading to higher N uptake (Fageria, 2009), which enhanced photoassimilates production and translocation into seeds (Przedonowek et al., 2004, Anderson, 2005 and Olowe and Adebime, 2009). Meanwhile, the negative results after silage maize might be due to the soil-low supply with organic $\mathrm{N}$ and / or greater $\mathrm{N}$ uptake from soil by the proceeding 
silage maize. Head seed weight, as an average of the two seasons for sunflower, grown in $\mathrm{Sun}_{4}, \mathrm{Sun}_{3}$ and $\mathrm{Sun}_{2}$ treatments, were $71.4,95.9$ and $97.9 \%$, respectively, of the Sun $_{1}$ head seed weight.

Table (2): Means of plant height, head diameter and weight of Seeds /Head as influenced by nitrogen levels, and cropping system and their interaction during 2013 and 2014 seasons.

\begin{tabular}{|c|c|c|c|c|c|c|}
\hline \multirow[t]{2}{*}{ Factor } & \multicolumn{2}{|c|}{ Plant height $(\mathrm{cm})$} & \multicolumn{2}{|c|}{$\begin{array}{c}\text { Head } \\
\text { diameter }(\mathrm{cm})\end{array}$} & \multicolumn{2}{|c|}{$\begin{array}{c}\text { Weight of } \\
\text { Seeds /Head(g) }\end{array}$} \\
\hline & 2013 & 2014 & 2013 & 2014 & 2013 & 2014 \\
\hline & \multicolumn{6}{|c|}{ Cropping system } \\
\hline $\operatorname{Sun}_{1}\left(S_{1}\right)$ & $154.55_{a}$ & $154.22_{a}$ & $9.68_{a}$ & $9.83_{a}$ & $35.06_{a}$ & $34.03_{b}$ \\
\hline $\operatorname{Sun}_{2}\left(\mathrm{~S}_{2}\right)$ & $153.22_{a}$ & $153.67_{a}$ & $9.44_{a}$ & $9.63_{a}$ & $34.13_{b}$ & $35.63_{a}$ \\
\hline $\mathrm{Sun}_{3}\left(\mathrm{~S}_{3}\right)$ & $151.89_{a}$ & $153.77_{\mathrm{a}}$ & $9.39_{a}$ & $9.56_{a}$ & $33.74_{b}$ & $34.54_{b}$ \\
\hline \multirow[t]{2}{*}{$\operatorname{Sun}_{4}\left(\mathrm{~S}_{4}\right)$} & $150.00_{a}$ & $153.83_{a}$ & $8.58_{b}$ & $8.37_{b}$ & $29.16_{c}$ & $34.07_{b}$ \\
\hline & \multicolumn{6}{|c|}{$\underline{\text { Nitrogen levels }}$} \\
\hline $\mathrm{N}_{1}$ & $147.67_{\mathrm{c}}$ & $151.58_{c}$ & $9.00_{a}$ & $9.00_{a}$ & $31.92_{b}$ & $32.23_{b}$ \\
\hline $\mathrm{N}_{2}$ & $153.08_{b}$ & $153.83_{b}$ & $9.26_{a}$ & $9.36_{a}$ & $33.03_{a}$ & $33.89_{a}$ \\
\hline \multirow[t]{2}{*}{$\mathrm{N}_{3}$} & $156.50_{a}$ & $156.08_{a}$ & $9.58_{a}$ & $9.69_{a}$ & $33.13_{a}$ & $34.06_{a}$ \\
\hline & \multicolumn{6}{|c|}{$\underline{\text { Cropping system *Nitrogen levels }}$} \\
\hline $\mathrm{S}_{1}{ }^{*} \mathrm{~N}_{1}$ & $148.66_{\mathrm{fg}}$ & $152.00_{\text {def }}$ & $9.33_{c}$ & $9.40 \mathrm{de}$ & $33.66_{d}$ & $34.26 \mathrm{de}$ \\
\hline $\mathrm{S}_{1}{ }^{*} \mathrm{~N}_{2}$ & $155.33_{b c}$ & $154.00 \mathrm{bcd}$ & $9.70_{b}$ & $9.86_{b}$ & $35.23 \mathrm{bc}$ & $35.83 b$ \\
\hline $\mathrm{S}_{1} * \mathrm{~N}_{3}$ & $159.66 \mathrm{a}$ & $156.66 \mathrm{a}$ & $10.00_{a}$ & $10.23 \mathrm{a}$ & $36.30 \mathrm{a}$ & $36.80_{a}$ \\
\hline $\mathrm{S}_{2}{ }^{*} \mathrm{~N}_{1}$ & $148.00 \mathrm{gh}$ & $151.00_{f}$ & $9.16_{d}$ & $9.26 \mathrm{e}$ & $33.10_{\mathrm{e}}$ & $33.23 f$ \\
\hline $\mathrm{S}_{2}{ }^{*} \mathrm{~N}_{2}$ & $154.00 \mathrm{~cd}$ & $154.00 \mathrm{bcd}$ & $9.40_{c}$ & $9.63_{c}$ & $34.00 d$ & $34.43 d$ \\
\hline $\mathrm{S}_{2}{ }^{*} \mathrm{~N}_{3}$ & $157.66 \mathrm{ab}$ & $156.00 \mathrm{ab}$ & $9.76_{b}$ & $10.00 \mathrm{~b}$ & $35.30_{b}$ & $35.96 \mathrm{~b}$ \\
\hline $\mathrm{S}_{3} * \mathrm{~N}_{1}$ & $148.00 \mathrm{gh}$ & $151.66_{\text {ef }}$ & $9.13_{d}$ & $9.23_{\mathrm{e}}$ & $32.66_{f}$ & $33.00 \mathrm{f}$ \\
\hline $\mathrm{S}_{3} * \mathrm{~N}_{2}$ & $152.33 \mathrm{de}$ & 153.66 cde & $9.36_{c}$ & $9.56 \mathrm{~cd}$ & $33.66_{d}$ & $34.00 \mathrm{e}$ \\
\hline $\mathrm{S}_{3} * \mathrm{~N}_{3}$ & $155.33 \mathrm{bc}$ & $156.00 \mathrm{ab}$ & $9.66_{b}$ & $9.86_{b}$ & $34.90_{c}$ & $35.20 \mathrm{c}$ \\
\hline $\mathrm{S}_{4}{ }^{*} \mathrm{~N}_{1}$ & $146.00_{h}$ & $151.66_{\text {ef }}$ & $8.30 \mathrm{~g}$ & $8.06_{h}$ & $28.23 i$ & $28.43_{i}$ \\
\hline $\mathrm{S}_{4}{ }^{*} \mathrm{~N}_{2}$ & 150.66 ef & $153.66_{\mathrm{cde}}$ & $8.56 f$ & $8.36 \mathrm{~g}$ & $29.20 h$ & $29.30 h$ \\
\hline $\mathrm{S}_{4} * \mathrm{~N}_{3}$ & $153.33 \mathrm{~cd}$ & $155.66 \mathrm{abc}$ & $8.86_{e}$ & $8.66_{f}$ & $30.03 \mathrm{~g}$ & $30.26 \mathrm{~g}$ \\
\hline $\mathrm{LSD}_{0.05}$ & 2.47 & 2.27 & 0.104 & 0.172 & 0.356 & 0.426 \\
\hline
\end{tabular}

(1) Means followed by the same letter(s) are not significant, but different letters are significant at 0.05 level. 
Table (3): Means of biological yield ,100-seed weight and seed yield as influenced by nitrogen levels, and cropping system and their interaction during 2013 and 2014 seasons.

\begin{tabular}{|c|c|c|c|c|c|c|}
\hline \multirow{2}{*}{ Factor } & \multicolumn{2}{|c|}{ Biological yield (kg/fed) } & \multicolumn{2}{|c|}{ 100-seed weight $(\mathrm{g})$} & \multicolumn{2}{|c|}{ Seed yield (kg/fed) } \\
\hline & 2013 & 2014 & 2013 & 2014 & 2013 & 2014 \\
\hline & \multicolumn{6}{|c|}{ Cropping system } \\
\hline $\operatorname{Sun}_{1}\left(S_{1}\right)$ & $1991.4 a$ & $2022.4 a$ & $7.77_{\mathrm{a}}$ & $7.91_{a}$ & $1200_{a}$ & $1122.3_{c}$ \\
\hline $\operatorname{Sun}_{2}\left(S_{2}\right)$ & $1930.9 b$ & $1965.1 \mathrm{a}$ & $7.53_{\mathrm{ab}}$ & $7.62 a_{b}$ & $1166_{b}$ & $1184.4_{a}$ \\
\hline $\operatorname{Sun}_{3}\left(\mathrm{~S}_{3}\right)$ & $1897.7 b$ & $1839.4 a b$ & $7.45_{b}$ & $7.55 a_{b}$ & $1146_{c}$ & $1168.3_{b}$ \\
\hline \multirow[t]{2}{*}{$\operatorname{Sun}_{4}\left(S_{4}\right)$} & $1638.9 c$ & $1598.7 b$ & $6.97_{\mathrm{c}}$ & $7.10_{b}$ & $979.4_{d}$ & $963.3_{d}$ \\
\hline & \multicolumn{6}{|c|}{ Nitrogen levels } \\
\hline $\mathrm{N}_{1}$ & $1799.2 \mathrm{c}$ & $1817.7 a$ & $7.16_{c}$ & $7.23_{b}$ & $1083.63_{b}$ & $1095.75_{b}$ \\
\hline $\mathrm{N}_{2}$ & $1857.9 b$ & $1890.5 a$ & $7.42_{b}$ & $7.599_{a}$ & $1123.43 a$ & $1133.53_{a}$ \\
\hline \multirow[t]{2}{*}{$\mathrm{N}_{3}$} & $1935.6 a$ & $1861.1 \mathrm{a}$ & $7.72_{a}$ & $7.82_{\mathrm{a}}$ & $1162.62_{a}$ & $1172.72_{\mathrm{a}}$ \\
\hline & \multicolumn{6}{|c|}{ Cropping system *Nitrogen levels } \\
\hline $\mathrm{S}_{1}{ }^{*} \mathrm{~N}_{1}$ & 1906.8 & 1931.13 & $7.43_{d}$ & $7.56_{\mathrm{de}}$ & $1146.66 \mathrm{de}$ & $1163.33 \mathrm{e}$ \\
\hline$S_{1}{ }^{*} N_{2}$ & 2008.07 & 2044.57 & $7.80 \mathrm{bc}$ & $7.96_{b}$ & $1213.33_{b}$ & $1231.66_{b}$ \\
\hline$S_{1}{ }^{*} N_{3}$ & 2059.4 & 2091.6 & $8.10_{a}$ & $8.20_{a}$ & $1240.00 \mathrm{a}$ & $1260.00 \mathrm{a}$ \\
\hline $\mathrm{S}_{2}{ }^{*} \mathrm{~N}_{1}$ & 1864.9 & 1903.5 & $7.26 \mathrm{e}$ & $7.36 \mathrm{f}$ & $1123.33_{f}$ & $1146.66_{f}$ \\
\hline $\mathrm{S}_{2}{ }^{*} \mathrm{~N}_{2}$ & 1908.2 & 1959.3 & $7.50 \mathrm{~d}$ & $7.63 \mathrm{~cd}$ & $1158.33 \mathrm{~d}$ & $1178.33 \mathrm{~d}$ \\
\hline $\mathrm{S}_{2}{ }^{*} \mathrm{~N}_{3}$ & 2019.5 & 2032.6 & $7.83 \mathrm{~b}$ & $7.86_{b}$ & $1216.66_{b}$ & $1228.33 \mathrm{~b}$ \\
\hline $\mathrm{S}_{3}{ }^{*} \mathrm{~N}_{1}$ & 1839.8 & 1875.8 & $7.20_{\mathrm{e}}$ & $7.26 \mathrm{fg}$ & $1108.33 \mathrm{~g}$ & $1130.00 \mathrm{~g}$ \\
\hline $\mathrm{S}_{3}{ }^{*} \mathrm{~N}_{2}$ & 1891.3 & 1967.2 & $7.43 \mathrm{~d}$ & $7.60_{d}$ & $1143.33 \mathrm{e}$ & $1165.00 \mathrm{de}$ \\
\hline $\mathrm{S}_{3}{ }^{*} \mathrm{~N}_{3}$ & 1961.9 & 1675.2 & $7.73_{c}$ & $7.80 \mathrm{bc}$ & $1186.66_{c}$ & $1210.00_{c}$ \\
\hline $\mathrm{S}_{4}{ }^{*} \mathrm{~N}_{1}$ & 1585.3 & 1560.2 & $6.73 \mathrm{~g}$ & $6.73_{\mathrm{h}}$ & $955.00_{j}$ & $940.00_{j}$ \\
\hline $\mathrm{S}_{4}{ }^{*} \mathrm{~N}_{2}$ & 1624.03 & 1590.8 & $6.966_{f}$ & $7.16 \mathrm{~g}$ & $978.33_{i}$ & $958.33_{i}$ \\
\hline $\mathrm{S}_{4}{ }^{*} \mathrm{~N}_{3}$ & 1701.6 & 1645.0 & $7.20 \mathrm{e}$ & 7.40 ef & $1005.00 \mathrm{~h}$ & $991.66 \mathrm{~h}$ \\
\hline $\mathrm{LSD}_{0.05}$ & - (2) & - & 0.089 & 0.199 & 12.23 & 14.31 \\
\hline
\end{tabular}

(1) Means followed by the same letter(s) are not significant, but different letters are significant at 0.05 level.

(2) The ignored L.S.D. indicates that $(\mathrm{S} \times \mathrm{N})$ interaction was not significant. 
Nawar, et al.,

Table (4): Means of harvest index, cereal units and nitrogen use efficiency as influenced by nitrogen levels, and cropping system and their interaction during 2013 and 2014 seasons.

\begin{tabular}{|c|c|c|c|c|c|c|}
\hline \multirow{2}{*}{ Factor } & \multicolumn{2}{|c|}{ H.I \% } & \multicolumn{2}{|c|}{ Cereal units (CUs) } & \multicolumn{2}{|c|}{$\begin{array}{l}\text { nitrogen use efficiency } \\
(\mathrm{LE} / \mathrm{kgN})\end{array}$} \\
\hline & 2013 & 2014 & 2013 & 2014 & 2013 & 2014 \\
\hline & \multicolumn{6}{|c|}{ Cropping system } \\
\hline $\operatorname{Sun}_{1}\left(S_{1}\right)$ & $32.96_{a}$ & $33.82_{a}$ & $17.95 a$ & $18.2 \mathrm{a}$ & $28.57 a$ & $26.80 c$ \\
\hline $\operatorname{Sun}_{2}\left(S_{2}\right)$ & $32.38_{a b}$ & $32.89_{b}$ & $17.49 b$ & $17.77 b$ & $27.82 b$ & $29.05 a$ \\
\hline $\operatorname{Sun}_{3}\left(S_{3}\right)$ & $31.96 \mathrm{~b}$ & $32.66_{b}$ & $17.19 c$ & $17.47 b$ & $27.38 \mathrm{c}$ & $28.28 b$ \\
\hline \multirow[t]{2}{*}{$\operatorname{Sun}_{4}\left(S_{4}\right)$} & $28.22_{c}$ & $28.67_{c}$ & $14.69 d$ & $14.45 \mathrm{c}$ & $23.44 d$ & $27.90 \mathrm{~b}$ \\
\hline & \multicolumn{6}{|c|}{$\underline{\text { Nitrogen patterns }}$} \\
\hline $\mathrm{N}_{1}$ & $30.51_{b}$ & $31.18_{b}$ & $16.22 \mathrm{c}$ & $16.39 \mathrm{c}$ & $36.11 a$ & $36.5 a$ \\
\hline $\mathrm{N}_{2}$ & $31.39_{a}$ & $31.95_{a}$ & $16.85 b$ & $17.00 \mathrm{~b}$ & $24.93 b$ & $25.19 b$ \\
\hline \multirow[t]{2}{*}{$\mathrm{N}_{3}$} & $32.222_{a}$ & $32.88_{a}$ & $17.44 a$ & $17.53 a$ & $19.36 c$ & $19.54 c$ \\
\hline & \multicolumn{6}{|c|}{ Cropping system *Nitrogen patterns } \\
\hline$S_{1}{ }^{*} N_{1}$ & $32.10_{\mathrm{cd}}$ & $32.90_{d}$ & 17.05 ef & $17.45 \mathrm{e}$ & $38.22 \mathrm{a}$ & $38.77 \mathrm{a}$ \\
\hline $\mathrm{S}_{1}{ }^{*} \mathrm{~N}_{2}$ & $32.83_{b}$ & $33.93_{b}$ & $18.18 b$ & $18.48 \mathrm{ab}$ & $26.82 \mathrm{e}$ & $27.37 \mathrm{e}$ \\
\hline $\mathrm{S}_{1}{ }^{*} \mathrm{~N}_{3}$ & $33.93 \mathrm{a}$ & $34.63 \mathrm{a}$ & $18.62 \mathrm{a}$ & $18.67 \mathrm{a}$ & $20.66 \mathrm{i}$ & $21.00 \mathrm{~g}$ \\
\hline $\mathrm{S}_{2}{ }^{*} \mathrm{~N}_{1}$ & $31.56_{d}$ & $32.03 \mathrm{e}$ & $16.85 f$ & $17.20 \mathrm{f}$ & $37.44 \mathrm{~b}$ & $38.22 \mathrm{~b}$ \\
\hline $\mathrm{S}_{2}{ }^{*} \mathrm{~N}_{2}$ & $32.56_{b c}$ & $32.66_{d}$ & $17.37 \mathrm{~d}$ & $17.68 \mathrm{~d}$ & $25.74 \mathrm{f}$ & $26.16 \mathrm{f}$ \\
\hline $\mathrm{S}_{2}{ }^{*} \mathrm{~N}_{3}$ & $33.00 \mathrm{~b}$ & $33.96_{b}$ & $18.25 \mathrm{~b}$ & $18.42 \mathrm{~b}$ & $20.28 \mathrm{j}$ & $20.47 \mathrm{~h}$ \\
\hline $\mathrm{S}_{3}{ }^{*} \mathrm{~N}_{1}$ & $30.90_{\mathrm{e}}$ & $31.83 \mathrm{e}$ & $16.62 \mathrm{~g}$ & $16.78 \mathrm{~g}$ & $36.94 \mathrm{c}$ & $37.66 \mathrm{c}$ \\
\hline $\mathrm{S}_{3}{ }^{*} \mathrm{~N}_{2}$ & $32.06_{c d}$ & $32.66_{d}$ & $17.15 \mathrm{e}$ & $17.47 \mathrm{e}$ & $25.41 \mathrm{~g}$ & $25.89 f$ \\
\hline $\mathrm{S}_{3}{ }^{*} \mathrm{~N}_{3}$ & $32.90 \mathrm{~b}$ & $33.46_{c}$ & $17.80 \mathrm{c}$ & $18.15 \mathrm{c}$ & $19.78 \mathrm{k}$ & $20.17 \mathrm{~h}$ \\
\hline $\mathrm{S}_{4}{ }^{*} \mathrm{~N}_{1}$ & $27.50_{h}$ & $27.96_{h}$ & $14.32 \mathrm{j}$ & $14.1 \mathrm{j}$ & $31.83 d$ & $31.33 \mathrm{~d}$ \\
\hline $\mathrm{S}_{4}{ }^{*} \mathrm{~N}_{2}$ & $28.10 \mathrm{~g}$ & $28.56 \mathrm{~g}$ & $14.67 \mathrm{i}$ & $14.37 \mathrm{i}$ & $21.74 \mathrm{~h}$ & $21.29 \mathrm{~g}$ \\
\hline $\mathrm{S}_{4}{ }^{*} \mathrm{~N}_{3}$ & $29.06_{f}$ & $29.46 f$ & $15.08 \mathrm{~h}$ & $14.89 \mathrm{~h}$ & 16.75 I & $16.52 \mathrm{i}$ \\
\hline LSD $_{0.05}$ & 0.582 & 0.404 & 0.21 & 0.20 & 0.328 & 0.302 \\
\hline
\end{tabular}

(1) Means followed by the same letter(s) are not significant, but different letters are significant at 0.05 level. 
The statistical analysis of seed yield/ fed. indicated significant differences among the four preceding crops. Data behaved similar over the two seasons. Results on seed yield/ fed, also, revealed that the highest seed yield of sunflower was obtained when the crop was relay-cropped into faba bean, whereas, it was inferior when sunflower was preceded by silage maize. These results might be attributed to the production of vigorous plants with a wide foliage in $\mathrm{Sun}_{1}$, compared to $\mathrm{Sun}_{4}$ treatment.That increased light uptake and photoassimilates production and translocation,these increasing number of seeds and individual seed weight with the final increase in seed yield/ fed (Khalil, 2003 and Khalil et al., 2004). Sinclair and Gardner (1998) attributed yield increases of a crop to increases in harvest index or to biological yield increase. As observed, the yield inferiority of $\left(\operatorname{Sun}_{4}\right)$, compared to $\left(\operatorname{Sun}_{1}\right)$ treatment, might be due to lower proximity in time of sunflower to faba bean that was coupled with greater resources depletion by silage maize before their access to sunflower (Khalil, 2003). Relay-cropping of sunflower into faba bean plants gave yield increase of $220.6,54.0$ and $34.0 \mathrm{~kg}$, in the first season, and 255.0, 49.7 and $33.9 \mathrm{~kg}$, , respectively, compared to $\mathrm{Sun}_{4}, \mathrm{Sun}_{3}$ and $\mathrm{Sun}_{2}$ treatments.

Concerning, $\mathrm{HI}$, as shown from data, this trait followed the same course of change with seed yield/ fed over the two seasons. Data obviously showed that the more the time proximity between sunflower and, the higher the yield obtained. Direct arrival of fixed $N$ (in Sun $_{1}$ ) by faba bean to sunflower increased $\mathrm{N}$ uptake that was associated with increasing the other growth nutrients (Fageria, 2009) which was reflected in the enhancement of dry matter translocation into the economic part (seeds) and increase $\mathrm{HI}$ (Gardner et al., 1985 and Sinclair and Gardner, 1998).
Differences in cereal units (CUs), among the four cropping patterns, were significant, greater for sunflower, as a relay-crop to faba bean $\left(\operatorname{Sun}_{1}\right)$, followed by $\operatorname{Sun}_{2}, \mathrm{Sun}_{3}$ and Sun $_{4}$, which ranked second, third and fourth to $\left(\operatorname{Sun}_{1}\right)$, respectively. These results might be attributed to the more availability of soil $\mathrm{N}$, with respect to $\mathrm{Sun}_{1}$ and $\mathrm{Sun}_{2}$ (relay or sequential cropping to faba bean), leading to higher $\mathrm{N}$ and other growth nutrients uptake (Fageria, 2009) , which enhanced photoassimilates production and translocation into vegetative and reproductive parts (Zamski and Schaffer, 1996). The lowest value of CUs was obtained when sunflower was proceeded by silage maize, which resulted from greater $\mathrm{N}$ uptake by silage and lower $\mathrm{N}$ available for sunflower which was reflected in CUs reduction, as a result of $\mathrm{HI}$ decline (Khalil et al., 2004 and Shaalan et al., 2015).

\section{2- Effect of nitrogen level on sunflower growth traits:}

Responses of sunflower growth traits to $\mathrm{N}$ levels (Tables 2, 3 and 4) were significant, except for number of leaves/ plant and head diameter, in both seasons.

There were significant differences in plant height with $\mathrm{N}$ level, where the more the $\mathrm{N}$ level, the taller plants were produced during the two seasons. Higher $\mathrm{N}$ application increased the level of its uptake, leading to vigorous vegetative growth and, consequently, taller sunflower plants (Sinclair and Gardner, 1998).

Data showed that the increases in head seed yield and 100-seed weight, were significant at 45, but insignificant at $60 \mathrm{~kg} \mathrm{~N} /$ fed, in both seasons. Compared to $N_{1}$, increases in 100-seed weight of $\mathrm{N}_{2}$ and $\mathrm{N}_{3}$ averaged 0.4 and $0.5 \mathrm{~g}$, respectively. However, $N_{2}$ and $N_{3}$ were superior to $N_{1}$ in that trait by 1.62 and $1.76 \mathrm{~g}$, as an average of both seasons, respectively. 
Application of nitrogen up to $45 \mathrm{~kg} / \mathrm{fed}$ led to a significant increase in seed yield/ fed., while, the further increase of $60 \mathrm{~kg} / \mathrm{fed}$ produced insignificant increase in that trait. Responses of sunflower seed yield to $\mathrm{N}_{1}, \mathrm{~N}_{2}$ and $N_{3}$ were, 1083.3, 1123.43 and 1162.1 $\mathrm{kg} /$ fed respectively, in the first season, corresponding to $1095.75,1133.53$ and $1172.72 \mathrm{~kg} / \mathrm{fed}$. in the second season. Lesser $\mathrm{N}$ uptake during seed development and maturity, as a result of applying lower $\mathrm{N}$ levels, might reduce photoassimilates partitioning into the developing seeds, resulting in small or infertile seeds (Loubser and Humam, 1993). This might explain the reductions in 100-seed weight and seed weight/ head. These results were in agreement with those reported by several investigators, who indicated that increasing $\mathrm{N}$ level increased plant height, 100-seed weight, weight of seeds/ head and seed yield/ fed. (Gewefiel et al., 1997; Halvorson et al., 1999 and Khalil, 2003).

Harvest index behaved similar to seed yield/ fed, as influenced by $\mathrm{N}$ level, during the two successive seasons. Sunflower HI indices reached the highest and the lowest values at the $N_{3}$ and $N_{1}$ levels, respectively. Increasing $\mathrm{N}$ level increased leaf generation and expansion, in terms of LAI, that was associated with great light interception, $\mathrm{N}$ use efficiency and assimilates greater translocation to seeds of a head (compared to the non-economic parts), resulting in an increase of sunflower harvest index (Gardner et al., 1985 and Sinclir and Gardner, 1998).

Data showed that the effect of $\mathrm{N}$ levels on cereal units (CUs) was significant during the two seasons. The $\mathrm{N}_{3}$ level produced the highest cereal units from sunflower, whereas, the least was obtained by the 30 $\mathrm{kgN}$ application. Lesser uptake of $\mathrm{N}$ and other growth resources, during seed development and maturity, as a result of applying lower $\mathrm{N}$ rates, might have reduced photoassimilates translocation into the developing seeds, resulting in a low production of seed and straw yields (Nawar, 2004 and Halvorson et al., 1999), hence a decrease in CUs.

The monetary net return, invested in one kilogram of applied $\mathrm{N}$, was inversely related to $\mathrm{N}$ rates, where, the maximum and minimum responses of 36.11 and 19.36 Egyptian pounds, in the first season, compared to 36.5 and 19.54 , in the second season, were produced from 30 and $60 \mathrm{kgN} /$ fed, respectively. Increasing $\mathrm{N}$ level might have increased production costs, which was not compensated for by a proportional increase in seed yield (Khalil, 2003).

The response equations of seed yield/head ,100-seed weight and seed yield to nitrogen fertilization levels indicated that these traits linearly increased as nitrogen fertilizer increased up to $45 \mathrm{~kg} \mathrm{~N} / \mathrm{fed}$. (Fig. 1). The coefficients of determination $\left(r^{2}\right)$ indicated that $54.2,90$ and $98 \%$ in the first season, in addition to 81,98 and $98 \%$, in the second season, of the total variation for these traits, respectively, were explained by the linear regression. That finding might indicate the possibility of increasing $\mathrm{N}$ level above $45 \mathrm{~kg} / \mathrm{fed}$. to obtain higher records of these characters.

\section{3- Cropping systems $\times \mathrm{N}$ levels interaction effect on sunflower traits:}

The interaction effects on some growth traits of sunflower followed the general trend of the two studied factors in both seasons.

Increases in values of head-seed weight were positively associated with time proximity of sunflower to faba bean and increases in $\mathrm{N}$ level, as well. As a result, the $S_{1} \times N_{3}$ and interactions $S_{4}{ }^{*} N_{1}$ produced the highest and lowest values of 36.55 and $28.33 \mathrm{~g}$, as an average of the two seasons, respectively. In addition, data in Table 2 , 3 


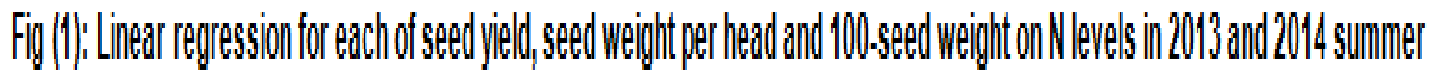
seasons,

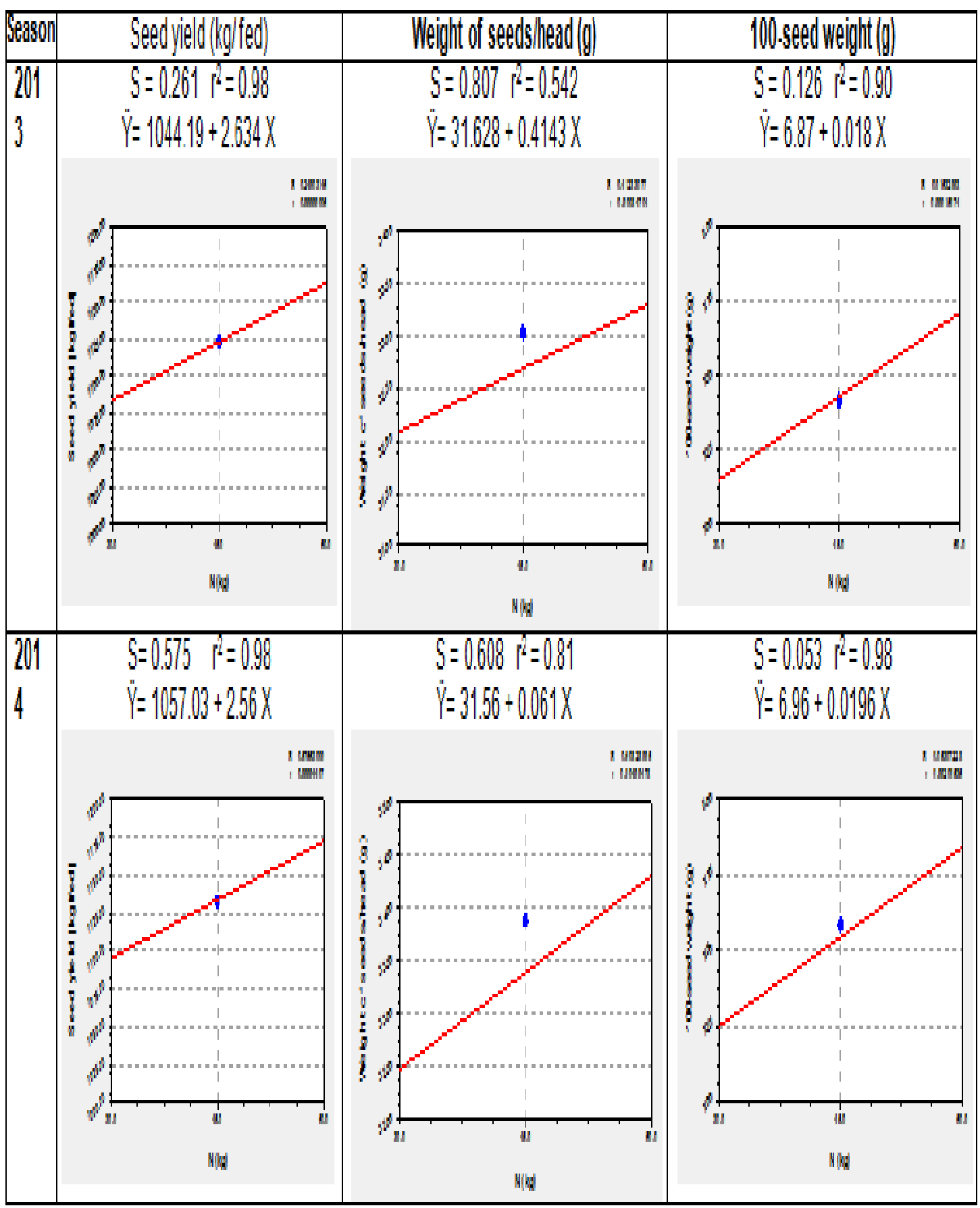


and 4 indicated that cropping system and $\mathrm{N}$ levels first order interaction, significantly affected both seed yield/ fed. and harvest index over the two seasons. Decreases in these traits resulted from a delay in sunflower sowing date (from time of Sun $_{1}$ to that of Sun $_{4}$ )by decreasing $\mathrm{N}$ level. Consequently, $S_{1} \times N_{3}$ interaction gave the highest values of yield and $\mathrm{HI}$, corresponding to the minimum ones obtained from $S_{4} \times N_{1}$ interaction in the two successive seasons. Increases in yield, with $\mathrm{S}_{1} \times \mathrm{N}_{3}$ combination, were 285 and $320 \mathrm{~kg} /$ fed in the two successive seasons, compared to $\mathrm{S}_{4}$ and $\mathrm{N}_{1}$ combined effect. On the other hand, the application of $\mathrm{Sun}_{4}$, with $\mathrm{N}_{1}$ level, led to a reduction in $\mathrm{HI}$ during the two seasons. Increasing $\mathrm{N}$ level, under the same cropping system, increased sunflowerharvest index, which reached the highest or lowest with $S_{1} \times N_{3}$ and $S_{4} \times N_{1}$ interactions, respectively. Application of $\mathrm{N}_{3}$ rate to a soil, higher in soil fertility ( $\mathrm{N}$ status, i.e. sun ${ }_{1}$ ), probably allowed the increase in photoassimlates production and translocation into grains, compared to the transfer into the vegetative parts (straw),resulting in the raise of sunflower harvest index (Shaalan et al.,2014 and Ibrahim et al., 2015)

Cropping systems and $\mathrm{N}$ levels combined effect on a monetary net return obtained from one kilogram of applied $\mathrm{N}$, was significant with the course of change over the two seasons. The 30 and $60 \mathrm{~kg} \mathrm{~N} / \mathrm{fed}$ produced the greatest and smallest values of that trait over the four preceding crops where returns attributed to the increase in seed yield did not compensate for the increased costs as $\mathrm{N}$ level increased. Differences in the economic use of one kilogram $\mathrm{N}$, within any of $\mathrm{N}$ level, varied with preceding crops. When sunflower was relaycropped into faba bean or sequentially followed it, there were increases in profits of lower $\mathrm{N}$ application where the more the soil was rich in organic matter, the lower response of sunflower to higher $\mathrm{N}$ levels.

\section{REFERENCES}

Anderson, R.L. (2005), Are some crops synergistic to following crops, Agron. J. 97: 7-10.

Brockhaus, F.A. (1962). Brockhaus ABC der land wirtschaft. Part 1: A-K.2 ${ }^{\text {nd }} E d$. Pp. 489.

EL-Nakhlawy, F.S. (1993). Defoliation effects on yield, yield components and quality of sunflower. Alex. J. Agric. Res., 38: 257- 267.

EL-Sodany, M.E. and A.M. Abou-Elela (2010). Effect of preceding winter crops relay cropping, intercropping system and nitrogen fertilizer on soil physical and chemical properties. J. of Soil Science and Agriculture Engineering 1: 273- 298.

Fageria, N.K. (2009). Nitrogen: pp. 31-91. In "The Use of Nutrients In Crop Plants" CRC press, Florida, USA.

Gardner, F.B., R.B. Peacre and R.L. Nitchell (1985). Physiology of Crop Plants. Iwa State Univ. press Ames, Iwa, USA.

Gewefiel, H.G.M., F.A.A. Osman and A.Y. EL-Banna (1997). Response of sunflower to phosphorus and nitrogen fertilizations under different plant densities in sandy soil. Zagazig J. Agric. Res. 24: 435- 448.

Ghosh, P.K., K.K. Bandyopadhyay, Manna, M.C. Wanjari, A.K. Misra, M. Mohanty and A. SubbaRas (2007). Legume effect for enhancing productivity and nutrient use-efficiency in major cropping systems.An Indian perspective. A Review. J. of Sustain Agric. 30: 59- 86.

Gomez, K.A. and A.A. Gomez (1984). Statistical Procedures for Agricultural Research. An International Rice Research Institute. Book John Willey and Sons. Inc., New York.

Halvorson, A.D., A.L. Black, H.H. Krupinsky, S.D. Merrill and D.L. Tanska (1999). Sunflower response to tillage and nitrogen fertilizer under intensive 
cropping system in wheat rotation. Agron. J. 91: 637- 642 .

Ibrahim, H.M., T.I.E. Abd EL-Wahab, A.I. Nawar and H.E. Khalil (2015). Maize response to different $\mathrm{N}$ levels following different preceding crops. Alex. Sci. Exch. J. 36: 213- 220.

Jannoura, R., R.G. Joergensen and C. Bruns (2014). Organic fertilizer effects on growth, crop yield and soil microbial biomass indices in sole and intercropped peas and oats under organic farming conditions. Europ. J. Agron. 52: 259270.

Khalil, H.E. (2003). Response of sunflower to different preceding crops and nitrogen fertilizer levels. Minufiya. J. Agric. Res. 28: 1899-1913.

Khalil, H.E., A.I. Nawar and A.S. Kamel (2004). Response of sunflower to multi seasonal crop sequences under different regimes of NPK fertilization. Alex. J. Agric. Res. 99: 13-23.

Khalil, H.E., A.I. Nawar, A.M. Abou-Elela, I.E. Mohammadein and M.E. EL-Sodany (2011). Response of maize to $\mathrm{N}$ fertilization following sunflower and preceding winter crops. Alex. J. Agric. Res. 56: 11-19.

Loubser, H.L. and J.J. Human (1993). The effect of nitrogen and phosphorus fertilization on the nitrogen absorption by sunflower. J. Agron. and Crop Sci. 170: 39-48.

Nawar, A.I. (2004). Nitrogen requirements for maize cultivars after different winter crops. J. Adv. Agric. Res. 9: 607- 621.

Nawar, A.I., I.E. Mohammadein and H.E. Khalil (2009). Response of maize to $\mathrm{N}$ fertilization and rotational crop sequences. Alex. J. Agric. Res. 54: 2939.

Olowe, V.I.O. and O.A. Adebime (2009). Intercropping sunflower with soybeans enhances total crop productivity. Bio. Agric. and Hort. 26 365- 377.

Przedonowek, D.W., M.H. Entz, B. Irvine, D.N. Flaten and J.R. Thiessen-Martens (2004). Rotational yield and apparent $\mathrm{N}$ benefits of green legumes in Southern Manitoba. Can. J. Plant Sci. 84: 10931096.

Rajaii, M. and M. Dah Mardeh (2014). The evaluation of corn and peanut intercropping on efficiency of use of the environmental resource and soil fertility. J. of Agric. Sci. 6: 99- 108.

Shaalan, A.M., Nagwa R. Ahmed, Shams S.A. Amr and H.E. Khalil (2014). Rotational crop sequences and $\mathrm{N}$ fertilization levels effect on maize growth and productivity. Alex. Sci. Exch. J. 35: 154- 161.

SAS Institute, Inc. (2007). SAS Technical Report SAS/STAT Software: Changes and Enhancements User's Guide, Volume 2, Version 9.1.3, Fourth Edition, Cary, NC: SAS Institute, Inc.

Sinclair, T.R. and E.P. Gardner (1998). Environment Limits to Plant production. Pp. 63- 78. In "Principles of Ecology in Plant Production" CBA, New York, USA.

Zamski, E. and A.A. Schaffer (1996). Photoassimilate Distribution in Plants and Crops. Source-Sink Relationships. Marcel Dekker, Inc. 
استجابة محصول دوار الثمس لنظم زراعية ومستويات من التسميد الآزوتى المختلفة

على عيسى نوار (1)، حسام الاين إبراهيم(1) ، حسن السيد خليل(2) - حلئ

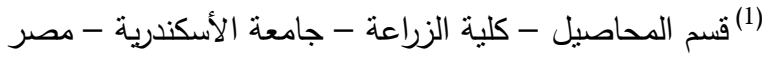

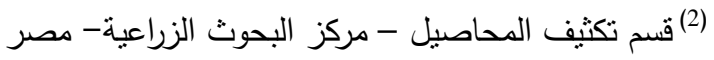

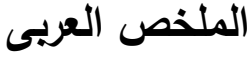

تمت دراسة استجابة محصول زهرة دوار الثمس لأربعة من نظم الزراعة تحت نأثير مستويات مختلفة من

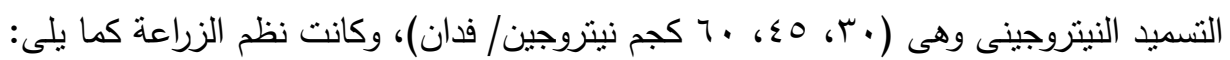

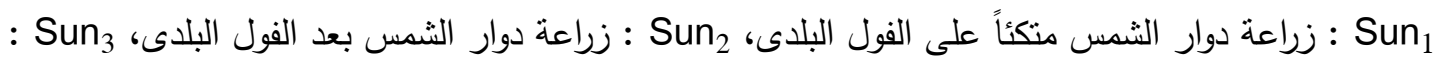

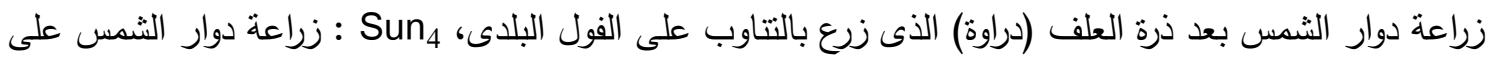
الفول البلدى بعد السيلاج الذى زرع بالتناوب على الفول البلائ.

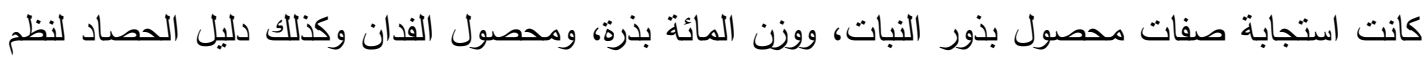

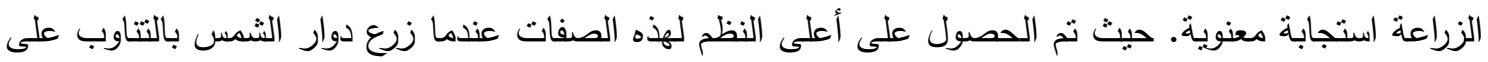

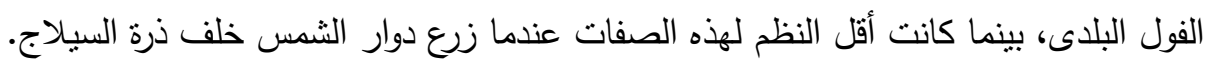

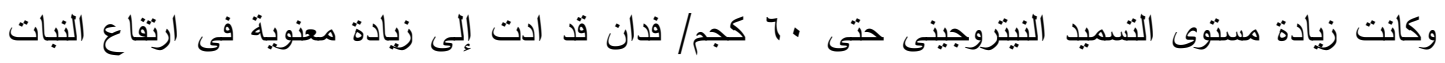
ومحصول القرص بجانب الزيادة فى كل من محصول الفدان ودلئل التيل الحصاد.

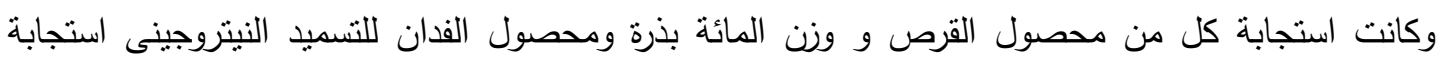
خطية و أوضحت البيانات أنه باستخدام التناوب الدحصولى مع المحاصيل قصيرة العمر بمكن زراعة أكثر من فئن

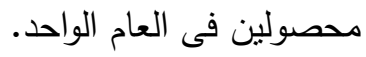


$\underline{\text { Response of sunflower to different cropping patterns and } \ldots \ldots \ldots \ldots \ldots \ldots \ldots \ldots \ldots \ldots \ldots \ldots \ldots \ldots}$ 
Nawar, et al., 